\title{
YIELD AND FORAGE QUALITY OF SALTBUSH IRRIGATED WITH REJECT BRINE FROM DESALINATION PLANT BY REVERSE OSMOSIS ${ }^{1}$
}

\author{
EDYMARA SINTHIA ROCHA DE MOURA*2; CHRISTIANO REBOUÇAS COSME ${ }^{3}$; NILDO DA SILVA DIAS ${ }^{3}$; \\ JEANE CRUZ PORTELA ${ }^{3}$; ANA CLAUDIA MEDEIROS SOUZA ${ }^{3}$
}

\begin{abstract}
Rural communities located in the Brazilian Northeast, especially in the semiarid zone, live with water shortages resulting from erratic rainfall. This work proposes the cultivation of saltbush (Atriplex nummularia) in the Rural Settlement Project of Boa Fé, Mossoró/RN as alternative to the disposal of reject brine from desalination plant on yield of forage. The statistical design was a split-plot design, being four treatments at the plots, related to irrigation with reject brine water, at different levels of soil moisture by moisture from Field Capacity (FC) (100, 85, 70 and 50\% of FC) and in subplots and two levels of organic manure (without fertilized and fertilized) with four replications. The variables of yield and forage quality of saltbush were analyzed. It was observed that saltbush has a great production capacity in terms of fresh matter and drought for saltbush under a level of $85 \%$ soil moisture in relation to the field capacity of soil, presenting minimal loss of yield; however, this proved to be productive even with the dry soil. The total yield was satisfactory, showing its viability for forage production.
\end{abstract}

Keywords: Atriplex nummularia. Water reuse. Salinity.

\section{PRODUÇÃO E QUALIDADE FORRAGEIRA DA ERVA SAL IRRIGADA COM REJEITO DA DESSALINIZAÇÃO POR OSMOSE REVERSA}

RESUMO - As comunidades rurais situadas no Nordeste brasileiro, em especial na região semiárida, convivem com a escassez de água resultante da irregularidade das chuvas nesta região. O presente trabalho propôs cultivar a erva sal (Atriplex nummularia) no Projeto de assentamento Rural Boa Fé, Mossoró/RN como alternativa à deposição do rejeito salino para a produção de forragem. $\mathrm{O}$ delineamento estatístico foi parcelas subdivididas, sendo quatro tratamentos nas parcelas, referentes a irrigação com rejeito salino em diferentes níveis de umidade do solo tendo como base a umidade na Capacidade de Campo (CC) (100, 85, 70 e 50\% da CC) e nas subparcelas, dois níveis de adubação orgânica (não adubado e adubado), com quatro repetições. Foram analisadas variáveis de produção e qualidade da forragem da erva sal. Observou-se que, a erva sal possui boa capacidade de produção de matéria fresca e seca sob um nível de $85 \%$ de umidade do solo em relação à sua capacidade de campo, apresentando mínimas perdas de rendimento, porém, mostrou-se produtiva mesmo com o solo mais seco. A produtividade total foi satisfatória mostrando sua viabilidade para a produção de forragem.

Palavras-chave: Atriplex nummularia. Reuso de água. Salinidade.

\footnotetext{
${ }^{*}$ Corresponding Author

${ }^{1}$ Received for publication in $02 / 04 / 2014$; accepted in $11 / 12 / 2015$.

Extracted from the first author's Master's dissertation, funded by CNPq.

${ }^{2}$ Universidade do Estado do Rio Grande do Norte, Mossoró, RN, Brazil; mara srm@hotmail.com.

${ }^{3}$ Department of Environmental Sciences and Technological, Universidade Federal Rural do Semi-Árido, Mossoró, RN, Brazil; christianoreboucas@ufersa.edu.br,nildo@ufersa.edu.br, jeane@ufersa.edu.br, anaclaudia.gambiental@hotmail.com.
} 


\section{INTRODUCTION}

In the Brazilian Northeast, especially in the semiarid region, irregular rainfalls cause a scarcity of shallow water deposits, resulting in a lack of water. In most rural communities of this region, the existence of this phenomenon is remarkable. However, it results in problems regarding the supply of drinking water. In view of this problem and the great potential groundwater resources, the drilling of wells to pump these waters has become a viable alternative commonly used for the irrigation of various horticulture areas through shallow wells with a low construction cost but with relatively high salt concentrations (SOUZA et al., 2009; DIAS et al., 2011; SOARES et al., 2015).

The drilling of wells has been used as a source of water for many rural communities of this region. However, even with groundwater being identified as a viable alternative to ensure access to water by rural communities in the Northeast, such sources of water present in most cases use restrictions for human consumption because of salinity problems (MEDEIROS et al., 2014; TERCEIRO NETO et al., 2014).

To minimize this problem, the Federal Government established the Freshwater Program. Its main objective is to solve the lack of water supply in these communities by installing and maintaining reject brine from desalination plant in rural communities to treat water from wells (SOARES et al., 2006). In Mossoró, this program has benefited about 50 communities.

Reverse osmosis is a technology widely used for the treatment of brackish water (PORTO et al., 2006), with successful experiences in most locations where desalting water treatment units are implemented. The use of reverse osmosis desalination has progressed remarkably, and the market and its applications are being considerably expanded. However, its economic aspect limits its expansion.

The deposition of the waste generated by treatment plants creates environmental concerns because of its high soil or water polluting capacity, if the process is not done correctly. In view of this, alternatives to this waste reuse are being studied. The use of evaporation tanks, tilapia and shrimp breeding and cultivation of halophytes are current alternatives more convenient to the destiny of this waste.
Regarding the cultivation of halophytes, Atriplex nummularia, also known as saltbush, has excelled in Brazil, being the object of several studies. Because it is from arid regions, Atriplex is especially important because it is able to produce and maintain an abundant biomass even in high aridity and salinity environments (PORTO et al., 2006). It is important to the phytoremediation process of soils affected by salts because it is convenient to the requirements of this process; it produces an abundant biomass in soils with a high salt content and tolerates drought, a common factor in arid and semi-arid areas (SOUZA et al., 2012).

From this perspective, this study aimed to use reject brine from desalination plant located at the settlement Project Boa Fé (Mossoró, RN) for the irrigation of saltbush (Atriplex nummularia) in order to evaluate its yield potential and forage quality.

\section{MATERIAL AND METHODS}

The experiment was conducted from September to December 2012 in the Settlement Project Boa Fé, located along the BR 304 highway, rural zone of the municipality of Mossoró, RN (geographical coordinates: $5^{\circ} 03^{\prime} 07.32^{\prime \prime} \mathrm{S}$ and $\left.37^{\circ} 20^{\prime} 22.42^{\prime \prime} \mathrm{W}\right)$. The experimental area was $180 \mathrm{~m}^{2}$. It is located near a brackish water treatment station, facilitating handling the saline waste to be used in research.

An irrigation system localized by gravity was chosen mainly because it does not require electrical power to operate. Microtube emitters of $1.5 \mathrm{~mm}$ in diameter and $1.5 \mathrm{~m}$ in length were used, resulting in an average flow rate of $5.0 \mathrm{~L} \mathrm{~h}^{-1}$. In order to standardize irrigation, both the irrigation hoses and the height of the water emission by the microtube were leveled in the entire experiment area. The Christiansen Uniformity Coefficient (CUC) was calculated, obtaining 93\% uniformity.

A reservoir for waste storage to be used for irrigation, with a capacity of $1,000 \mathrm{~L}$, was placed on a wooden structure at a $2.0 \mathrm{~m}$ height. It was installed in the center of the experimental area for a better distribution of irrigation water to plants. The chemical composition of the reject brine from desalination plant by reverse osmosis used in irrigation is shown in Table 1.

Table 1. Physical and chemical characteristics of the reject brine from desalination plant used in the irrigation of

\begin{tabular}{|c|c|c|c|c|c|c|c|c|c|c|c|c|}
\hline $\mathrm{pH}$ & $\mathrm{EC}$ & $\mathrm{K}^{+}$ & $\mathrm{Na}^{+}$ & $\mathrm{Ca}^{2+}$ & $\mathrm{Mg}^{2+}$ & $\mathrm{Cl}^{-}$ & $\mathrm{CO}_{3}{ }^{2-}$ & $\mathrm{HCO}_{3}^{-}$ & $\mathrm{SAR}^{1}$ & Hardness & $\sum$ Cations & ¿Anions \\
\hline (water) & $\mathrm{dS} \mathrm{m}^{-1}$ & & ----. & -.-- & $\mathrm{mmol}_{\mathrm{c}}$ & - & ---------- & & - & $m g L^{-1}$ & \multicolumn{2}{|c|}{--- $\mathrm{mmol}_{\mathrm{c}} \mathrm{L}^{-1}$} \\
\hline 6,92 & 9,35 & 0,63 & 43,23 & 40,60 & 31,40 & 154,00 & 8,00 & 0,00 & 7,2 & 3600 & 115,96 & 162,00 \\
\hline
\end{tabular}

${ }^{1} \mathrm{SAR}=\mathrm{Na}^{+} /\left[\left(\mathrm{Ca}^{2+}+\mathrm{Mg}^{2+}\right) / 2\right]^{1 / 2}$ 
The experimental design was a split plot design with four treatments related to soil moisture levels based on moisture of Field Capacity (FC) in plots and subplots and two levels of organic fertilization, with four replications and two plants per subplot, totaling 64 plants. Based on the soil water retention curve, the voltage at field capacity was set to $6 \mathrm{kPa}(60 \mathrm{~cm} . \mathrm{ca})$ and the moisture in FC corresponded to $0.1456 \mathrm{~cm}^{3} \mathrm{~cm}^{-3}$. This voltage to determine FC in the experiment was adopted because the soil is granulometrically classified as sandy loam based on the function of the level of sand, silt and clay, which provides it with relevant drain power. In addition, several authors have postulated that the field capacity for tropical soils corresponds to voltages ranging from 6 to $10 \mathrm{kPa}$ (MELLO et al., 2002; ANDRADE; STONE, 2011).

The effects of irrigation with reject brine water, at different levels of soil moisture were tested. The treatment of the plots was thus determined as $\mathrm{T}_{1}=100 \%$ of FC $\left(0.1456 \mathrm{~cm}^{3} \mathrm{~cm}^{-3}\right)$, $\mathrm{T}_{2}=85 \%$ of FC $\left(0.1238 \mathrm{~cm}^{3} \mathrm{~cm}^{-3}\right), \mathrm{T}_{3}=70 \%$ of FC $\left(0.1019 \mathrm{~cm}^{3} \mathrm{~cm}^{-3}\right)$ and $\mathrm{T}_{4}=50 \%$ of FC $\left(0.0728 \mathrm{~cm}^{3}\right.$ $\left.\mathrm{cm}^{-3}\right)$. In the subplots, the treatments were without fertilization $\left(\mathrm{F}_{0}\right)$ and with an organic fertilizer $\left(\mathrm{F}_{1}\right)$. The organic feedstock was goat manure in the amount of $1.5 \mathrm{~L}$ per plant. The fertilizer was manually applied in a single dose on $15 \mathrm{~cm}$-deep holes lateral to the plant.

Irrigation was performed daily. Based on the average readings from strains of water in the soil using tensiometers installed in each experimental plot, the current soil moisture was obtained in each treatment using the soil water retention curve, allowing calculation of the volume of irrigation necessary to maintain the soil moisture levels proposed by the treatments.

At the beginning of the experiment, all plants that were six months were cut, maintaining the height and the crown diameter at $40 \mathrm{~cm}$ with the aid of a cylindrical-shaped mold made of PVC with these dimensions in order to standardize the size of the plants, thus facilitating the measurement of production at the end of the production cycle, the moment when the cutting was carried out (harvest) after three months of cultivation.

Before the saltbush cutting, measurements of the crown diameter $(\mathrm{CD})$ and plant height $(\mathrm{PH})$ of all plants were performed. Then, there was a cutting of all separated material into leaves and stems to determine leaf fresh matter (LFM), stem fresh matter (SFM), and total fresh matter (TFM) by the sum of LFM and SFM. Leaf dry matter (LDM) and stem dry matter (SDM) were obtained after drying the material in an oven with forced air circulation at $65^{\circ}$ $\mathrm{C}$ until constant weight. The total dry matter (TDM) was obtained by the sum of LDM and SDM.

To evaluate the quality of the forage produced by saltbush, the percentage of dry matter (DM) and levels of organic matter (OM), mineral matter (MM) and crude protein $(\mathrm{CP})$ were determined according to the methodology described by Silva and Queiroz (2002)

The data were submitted to ANOVA and regression for a quantitative treatment of plots and to an average test of subplots using Assistat ${ }^{\circledR}$ software (SILVA; AZEVEDO, 2009).

\section{RESULTS AND DISCUSSION}

All growth and production variables of saltbush analyzed suffered significant linear effects influenced by the soil moisture levels to which the plants were submitted. However, organic fertilization did not significantly affect any of the variables; i.e., in production terms, Atriplex nummularia did not respond to the fertilization performed in the present study, proving to be a plant with rustic features in this respect (Table 2).

Plant height $(\mathrm{PH})$ and crown diameter (CD) were reduced with decreasing soil moisture according to the different percentages of field capacity of the soil to which they were submitted (Figure 1). Considering the $40 \mathrm{~cm}$ cutting height to which the plants were submitted at the beginning of the experiment, treatment $\mathrm{T}_{1}$, at the end of three months of culture, had an average $\mathrm{PH}$ of $83.13 \mathrm{~cm}$, that is, an increase of $43.13 \mathrm{~cm}$, a value higher than the other treatments of $75.19,71.75$ and $69.75 \mathrm{~cm}$ for $\mathrm{T}_{2}, \mathrm{~T}_{3}$ and $\mathrm{T}_{4}$ respectively. These results show the regrowth ability of Atriplex nummularia, a characteristic that influences its production capacity. Souza et al. (2012) reported a $45.25 \mathrm{~cm}$ recovery of saltbush height in relation to cutting height, which was $60 \mathrm{~cm}$, after four months of cultivation in a sodium saline soil under field conditions.

Moreover, the material resulting from regrowth showed to be tenderer for branches, not exceeding $1 \mathrm{~cm}$ in diameter, facilitating its use as forage for animals, in this particular case for goats. The literature shows that saltbush can reach over 2.0 $\mathrm{m}$ in height in the first year of cultivation and can reach 2-3 $\mathrm{m}$ in five years (PORTO et al., 2006).

Crown diameter had a similar behavior. However, differences between treatments were lower. $\mathrm{T}_{1}$ had a $75.16 \mathrm{~cm} \mathrm{CD}$ average while the others were $67.94,62.94$ and $60.16 \mathrm{~cm}$ for $\mathrm{T}_{2}, \mathrm{~T}_{3}$ and $\mathrm{T}_{4}$ respectively. These results allow inferring that the spacing adopted for the cultivation of Atriplex can be modified according to the purpose of planting. When the aim is to cut saltbush to supply it fresh to animals, the silage or hay production may reduce the spacing, thereby increasing productivity. Vasconcellos (2011) obtained a productivity of 44,250 and 18,632 $\mathrm{kg} \mathrm{ha}^{-1}$ of Fresh and Dry matter respectively by using a 1 x $1 \mathrm{~m}$ spacing and irrigating the Atriplex with effluents from the creation of tilapia with wastewater from desalination and performing cutting only at six months of 
cultivation. In the present study, the cutting of saltbush was performed three months after the previous cut. This management allows using a more dense spacing. Moreover, the density may allow for a more efficient extraction of salts per soil area.
There was a reduction in Fresh Matter due to the reduction of soil moisture in the treatments, showing that Atriplex nummularia, despite being considered a halophyte resistant to drought, decreases its productivity when kept under reduced water conditions (Figure 2).

Table 2. Summary of the analysis of variance for the variables Leaf Fresh Matter (LFM), Stem Fresh Matter (SFM), Leaf Dry Matter (LDM), Stem Dry Matter (SDM), Plant height (PH), Crown Diameter (CD), Total Fresh Matter (TFM) and Total Dry Matter (TDM).

\begin{tabular}{|c|c|c|c|c|c|c|c|c|c|}
\hline \multirow{2}{*}{ SV } & \multirow{2}{*}{$\mathrm{DF}$} & \multicolumn{8}{|c|}{ MS } \\
\hline & & LFM & SFM & LDM & SDM & $\mathrm{PH}$ & $\mathrm{CD}$ & TFM & TDM \\
\hline $\begin{array}{l}\text { Soil } \\
\text { moisture } \\
\text { leveis } \\
\text { (SML) }\end{array}$ & 3 & 343716,916 & 54965,647 & 17431,728 & 9832,924 & 277,778 & 346,46 & 662403,909 & 51538,405 \\
\hline $\begin{array}{l}\text { Linear } \\
\text { regression }\end{array}$ & 1 & $971926,437 * *$ & $132897,129 * *$ & $49446,305^{* *}$ & $23223,74 * *$ & $759,076^{*}$ & $1000,00 * *$ & $1823617,09 * *$ & $140444,085^{* *}$ \\
\hline $\begin{array}{l}\text { Quadratic } \\
\text { regression }\end{array}$ & 1 & $1502,62^{\mathrm{ns}}$ & $5550,262^{\text {ns }}$ & $300,374^{\mathrm{ns}}$ & $2003,535^{\text {ns }}$ & $70,507^{\mathrm{ns}}$ & $39,382^{\mathrm{ns}}$ & $1277,095^{\mathrm{ns}}$ & $752,380^{\text {ns }}$ \\
\hline $\begin{array}{l}\text { Cúbic } \\
\text { regression }\end{array}$ & 1 & $57721,69^{\text {ns }}$ & $26449,551^{\mathrm{ns}}$ & $2548,505^{\mathrm{ns}}$ & $4271,488^{\text {ns }}$ & $3,751^{\mathrm{ns}}$ & $0,00000^{\mathrm{ns}}$ & $162317,537^{\mathrm{ns}}$ & $13418,751^{\mathrm{ns}}$ \\
\hline $\begin{array}{l}\text { Residue } \\
\text { (SML) }\end{array}$ & 12 & 36029,81 & 8761,863 & 2713,633 & 1587,936 & 108,684 & 73,316 & 77192,637 & 7968,048 \\
\hline Plots & 15 & & & & & & & & \\
\hline $\begin{array}{l}\text { Fertilization } \\
\text { (F) }\end{array}$ & 1 & $16815,171^{\mathrm{ns}}$ & $16408,227^{\mathrm{ns}}$ & $2209,044^{\mathrm{ns}}$ & $3378,161^{\mathrm{ns}}$ & $2,257^{\mathrm{ns}}$ & $13,132^{\mathrm{ns}}$ & $66444,341^{\mathrm{ns}}$ & $11050,706^{\mathrm{ns}}$ \\
\hline $\begin{array}{l}\text { Interaction } \\
(\mathrm{SML}) \times(\mathrm{F})\end{array}$ & 3 & $63706,651^{\mathrm{ns}}$ & $21668,984^{\mathrm{ns}}$ & $3399,113^{\text {ns }}$ & $3267,872^{\text {ns }}$ & $91,507^{\mathrm{ns}}$ & $77,565^{\text {ns }}$ & $146438,868^{\mathrm{ns}}$ & $12372,547^{\mathrm{ns}}$ \\
\hline Resíduo (F) & 12 & 66739,862 & 16673,776 & 3463,728 & 2395,5 & 50,236 & 42,233 & 145593,495 & 11313,554 \\
\hline TOTAL & 31 & & & & & & & & \\
\hline $\begin{array}{l}\text { CV\% } \\
\text { (SML) }\end{array}$ & & 26,25 & 34,01 & 29,52 & 34,92 & 13,91 & 12,87 & 27,83 & 30,72 \\
\hline $\mathrm{CV} \%(\mathrm{~F})$ & & 35,73 & 46,42 & 33,35 & 42,89 & 9,46 & 9,77 & 38,23 & 36,61 \\
\hline
\end{tabular}

$* *=$ significant at 0,01 probability; $*=$ significant at 0,05 probability; ${ }^{\text {ns }}=$ not significant.

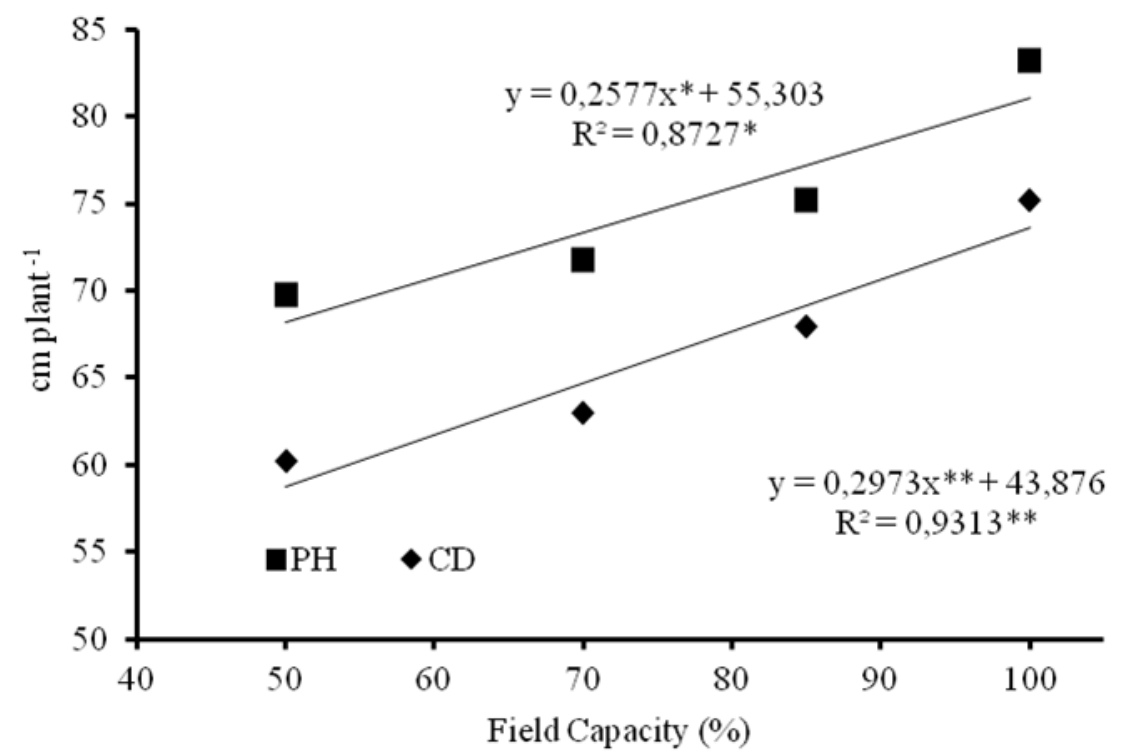

Figure 1. Linear regression equations relating plant height $(\mathrm{PH})$ and crown diameter (CD) of saltbush (Atriplex nummularia L.) irrigated with waste from desalination differing in soil moisture level. 


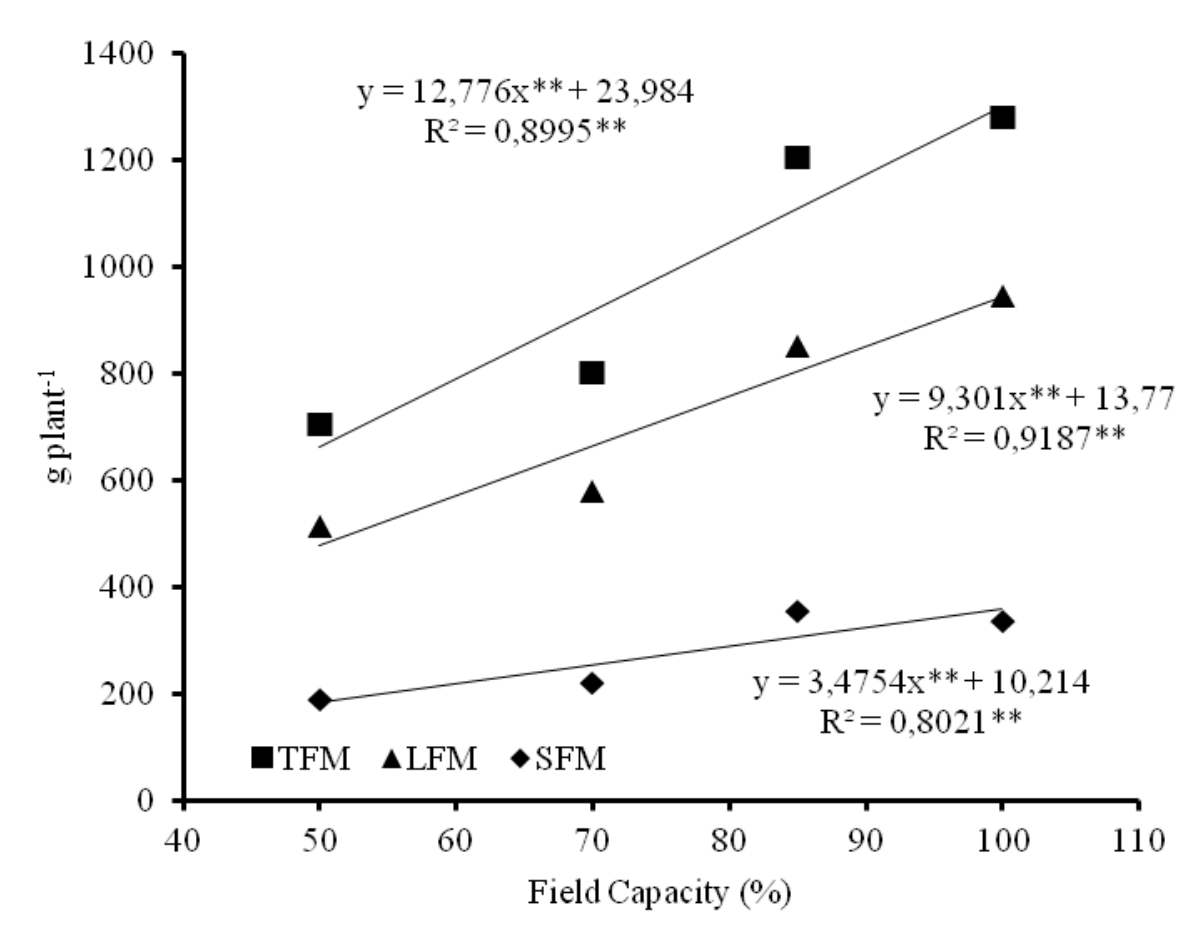

Figure 2. Linear regression equations relating Leaf Fresh Matter (LFM), Stem Fresh Matter (SFM) and Total Fresh Matter (TFM) of saltbush irrigated with waste from desalination differing in soil moisture level.

The greatest losses occurred in the leaves, where reductions in LFM were 9.91, 38.47 and $45.48 \%$ in $\mathrm{T}_{2}, \mathrm{~T}_{3}$ and $\mathrm{T}_{4}$ respectively, compared to treatment $T_{1}$. This same tendency occurred with TFM. However, because of the behavior of $T_{2}$ 's SFM, where there was no reduction in comparison to the control; the decrease in TFM for this treatment was only $5.74 \%$ when compared to the control.

A similar behavior was observed by Souza et al. (2012). In their study regarding leaf fresh matter, the treatments with 75 and $95 \%$ of FC did not differ and surpassed the others ( 35 and $55 \%$ of FC) when cultivating Atriplex nummularia in pots with a harvest at 134 days after transplanting. As for stem fresh matter, the treatment with $75 \%$ of $\mathrm{FC}$ was higher than the others, promoting an increased production. The authors obtained a 90.95 g plant $^{-1}$ of LFM for the treatment with $95 \%$ of FC, ten times lower than that obtained in this study for $100 \%$ of FC, which was 944.65 g plant $^{-1}$. This is because the authors harvested saltbushes at 134 days after transplantation, that is, the period of the first cut, which differs from the present study where data were obtained from a second cut three months after the first cut, the period when a greater stimulus to the regrowth of branches occurred.
These results show that Atriplex nummularia, under the conditions to which it was submitted during the study, barely reduced its yield with soil moisture kept at $85 \%$ of FC, proving its ability to tolerate water stress at this level. This represents an adaptive advantage of this species regarding the local climate and in terms of the effect of the frequent droughts. It is therefore an alternative to forage production for small farmers given its possibility to be used as a forage species.

The behavior of Dry Matter was similar to that of Fresh Matter (Figure 3). LDM was superior to SDM for all treatments. Regarding LDM, the reductions were 36.99 and $42.71 \%$ in $\mathrm{T}_{3}$ and $\mathrm{T}_{4}$, compared to the control, respectively, while, for $\mathrm{T}_{2}$, the decrease in LDM was $11.09 \%$. In any case, it was observed for TDM that the difference between $\mathrm{T}_{1}$ and $\mathrm{T}_{2}$ was only $3.54 \%$ or less. The obtained productions were 365.44 and $352.51 \mathrm{~g} \mathrm{\text {plant } ^ { - 1 }}$ respectively.

For SDM, treatment $\mathrm{T}_{2}(85 \%$ of $\mathrm{FC})$ had a value higher than the control treatment $(100 \%$ of FC), corroborating the results of Souza et al. (2012), who obtained a higher value for this variable for a treatment with $75 \%$ of $\mathrm{FC}$ compared to the control (95\% of FC). 


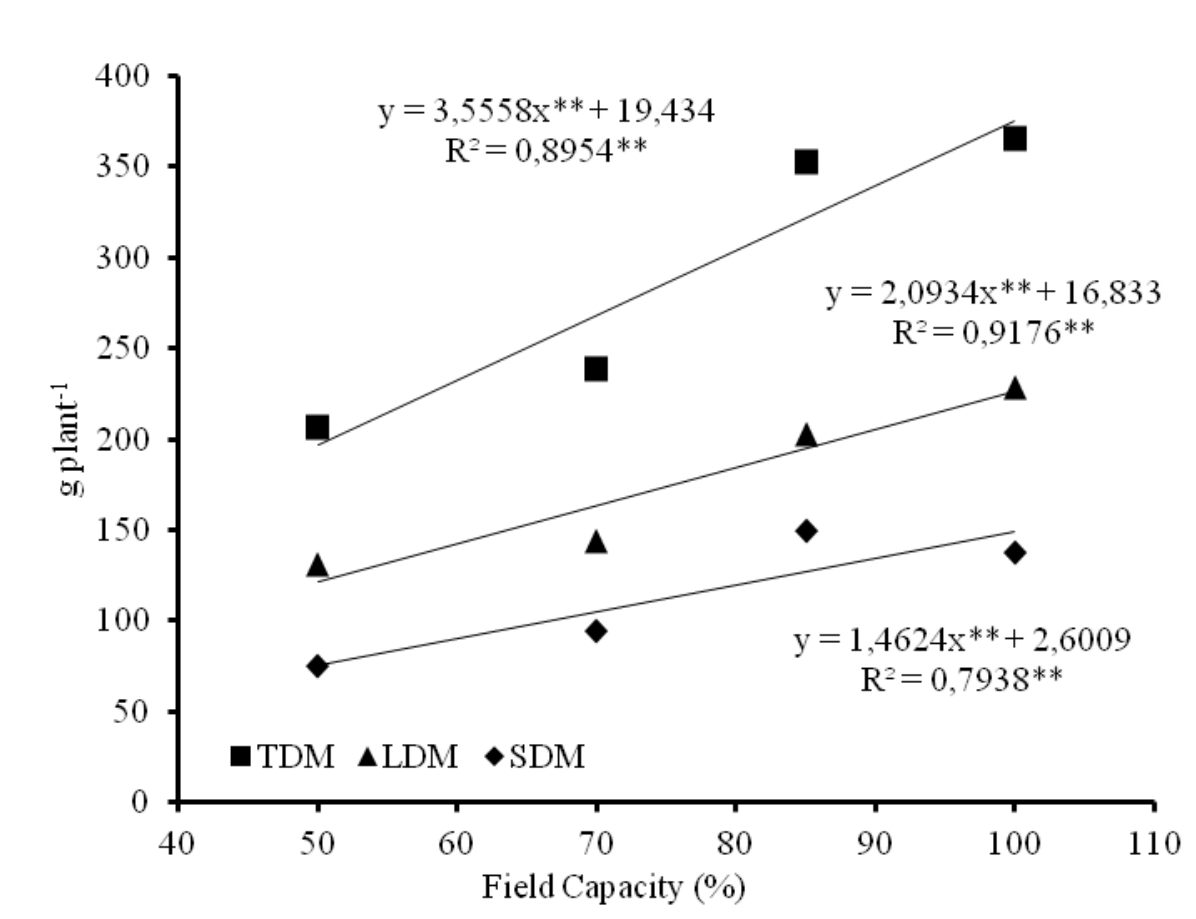

Figure 3. Linear regression equations relating Leaf Dry Matter (LDM), Stem Dry Matter (SDM) and, Total Dry Matter (TDM) of saltbush irrigated with waste from desalination differing in soil moisture level.

By extrapolating the results of saltbush production of TFM and TDM, considering the spacing used $(1.5 \times 1.5 \mathrm{~m})$, the values of yield were obtained in $\mathrm{kg} \mathrm{ha}^{-1}$ and in $\mathrm{kg} \mathrm{ha}^{-1}$ year $^{-1}$ (Table 3 ).

Table 3. Total yield based on Total Fresh Matter (TFM) and Total Dry Matter (TDM) of Atriplex nummularia irrigated with waste from desalination.

Total Yield

\begin{tabular}{ccccc} 
& & & & ------- $\mathrm{kg} \mathrm{ha}^{-1} \mathrm{year}^{-1}$------ \\
\cline { 2 - 4 } & Treatment & TDM & TFM & TDM \\
\hline $\mathrm{T}_{1}$ & 5689,62 & 1624,00 & 22758,49 & 6496,00 \\
$\mathrm{~T}_{2}$ & 5363,07 & 1566,56 & 21452,30 & 6266,24 \\
$\mathrm{~T}_{3}$ & 3564,92 & 1059,05 & 14259,69 & 4236,19 \\
$\mathrm{~T}_{4}$ & 3126,08 & 915,41 & 12504,31 & 3661,65 \\
\hline Average & 4435,92 & 1291,25 & 17743,69 & 5165,02 \\
\hline
\end{tabular}

The productivity reached $5,689.62$ and $1,624.00 \mathrm{~kg} \mathrm{ha}^{-1}$ of FM and DM respectively for the treatment at $100 \% \mathrm{FC}$ while the extrapolated yield for one year was 22,758.49 and 6,496.00 kg ha-1 year -1 for FM and DM respectively in the same treatment. These values are very close to those obtained by Porto et al. (2006), who obtained $21,296.00 \mathrm{~kg} \mathrm{ha}^{-1}$ year of FM and $6,537.00 \mathrm{~kg} \mathrm{ha}^{-1}$ year $^{-1}$ of DM considering saltbush forage irrigated with $75 \mathrm{~L}$ of wastewater from desalination per plant per week. According to Porto et al. (2006), saltbush yields normally ranged from 5 to $15 \mathrm{Mg} \mathrm{ha}^{-1}$ year $^{-1}$ of dry matter, and most of the results were between 6 and $8 \mathrm{mg} \mathrm{h}^{-1}$ year $^{-1}$, thus corroborating this study. This is considered a result compatible with several other forages irrigated with water adequate for irrigation, such as alfalfa. Barroso et al. (2006), using effluents from tilapia breeding to irrigate Atriplex, obtained yields higher than in this study by varying the volume of effluent applied from 75 to $300 \mathrm{~L}$ per week per plant, reaching a maximum productivity of $11,416.0 \mathrm{~kg} \mathrm{ha}^{-1}$ year $^{-1}$ of forage DM.

Considering the local climate under the environmental perspective of reusing waste from desalination, the results of this study point to Atriplex nummularia as a potential alternative to deposit waste, providing small producers with the possibility of producing forage during droughts using low-quality water since the saltbush's ability to produce forage under water stress was very evident in this study.

The allocation of Fresh Matter occurred more 
in leaves $(72.49 \%)$ than in stems $(27.51 \%)$, showing a greater production capacity of the leaf forage fraction in comparison with stems (Figure 4A). Considering Dry Matter, the proportion of stems increases to $39.03 \%$, proving the importance of this forage fraction in the final composition of dry matter (Figure 4B).

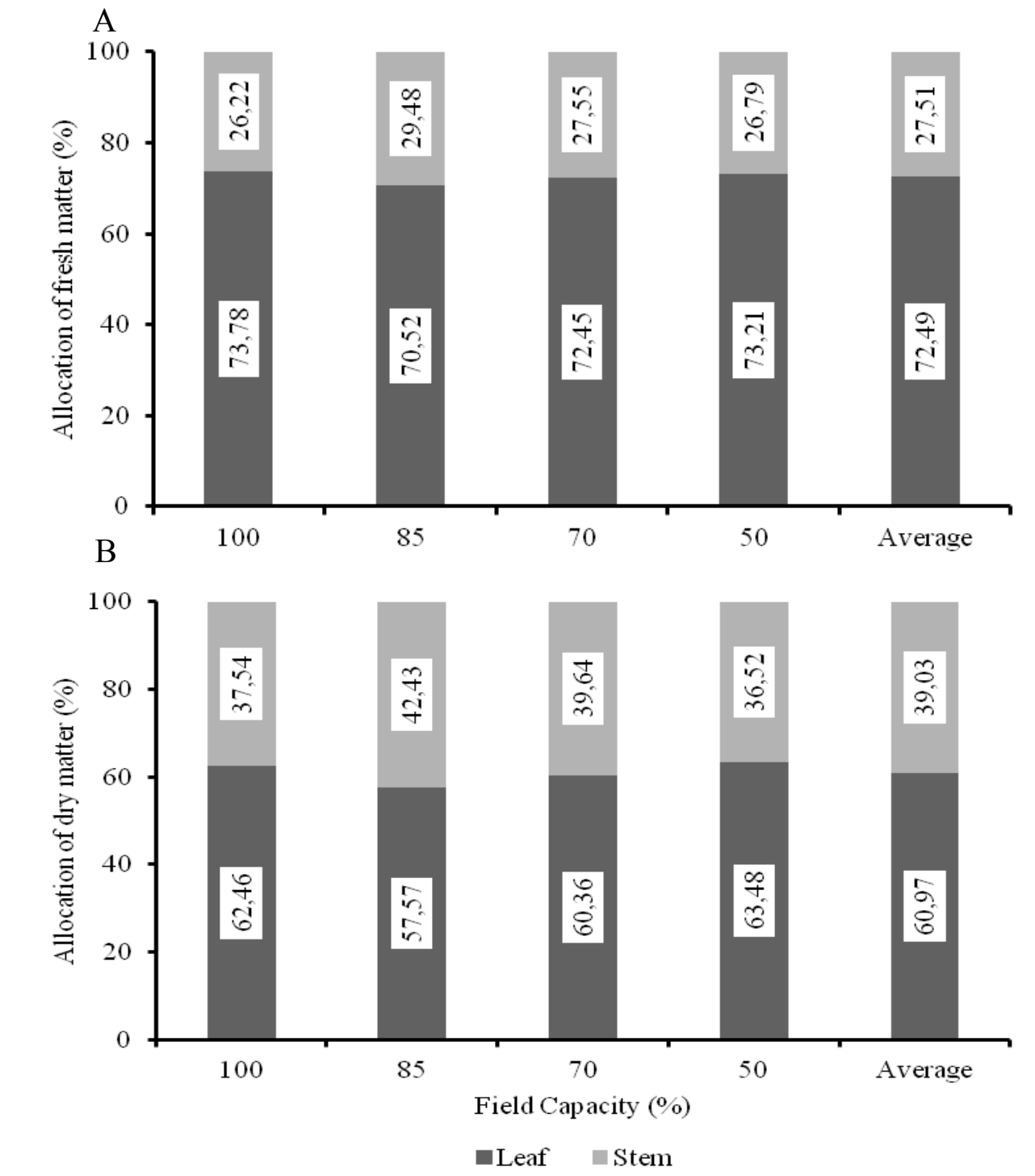

Figure 4. Allocation of Fresh (A) and Dry Matter (B) of saltbush on leaf and stem forage fractions differing in soil moisture level.

The forage fractions analyzed, leaf and stem, were not very sensitive to water levels in the soil to which they were submitted since, among bromatological composition variables, only DM suffered a significant effect $(\mathrm{P}>0.05)$ regarding the stem. For the leaf fraction, except for $\mathrm{CP}$, all other variables were significantly influenced by soil moisture. The fertilization did not significantly affect any of the variables analyzed for leaves and stems (Table 4).

The levels of crude protein (CP) in the leaves were, for all treatments, close to $15 \%$ (Table 5), showing that saltbush has good forage quality. These values are in agreement with those obtained by Barroso et al. (2006), who obtained a maximum of $15.79 \%$ at 12 months after planting, values above the values obtained by Watson and O'Leary (1993).

On the other hand, Porto et al. (2001) reported mean levels of $\mathrm{CP}$ of leaves of $18.7 \%$ and $18.5 \%$ respectively, confirming that saltbush leaves hold good levels of crude protein, levels that may be compared with those of some legumes and other species often used in animal feed, such as Leucaena, Gliricidia, forage guandu pea and maniçoba, which in general have between 12 and $22 \%$ of crude protein (CARVALHO JUNIOR et al., 2010). As for 
the stem, the CP content was lower if compared to leaves (Table 5) and below the values obtained by Barroso et al. (2006).

Overall, CP results show relevant Atriplex characteristics as forage even under low soil moisture conditions, allowing use of it in feed for livestock in areas frequently lacking rain, such as the Brazilian semiarid region, since the critical content for animal consumption is $7 \%$ of $\mathrm{CP}$ in dry matter. For a good performance of lactating cows, forage should contain approximately $15 \%$ of $\mathrm{CP}$; for growing animals, the $11-12 \%$ level is acceptable.

Table 4. Summary of the analysis of variance of the variables Crude Protein (CP), Mineral Matter (MM), Organic Matter (OM) and Dry Matter (DM) of leaves and stems of saltbush.

\begin{tabular}{|c|c|c|c|c|c|c|c|c|c|}
\hline \multirow{3}{*}{ SV } & \multirow{3}{*}{$\mathrm{DF}$} & \multicolumn{8}{|c|}{ MS } \\
\hline & & \multicolumn{4}{|c|}{ 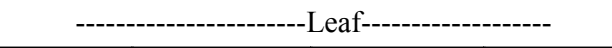 } & \multicolumn{4}{|c|}{--------------------Stem---------------- } \\
\hline & & $\mathrm{CP}(\%)$ & MM & $\mathrm{OM}$ & $\mathrm{DM}$ & $\mathrm{CP}(\%)$ & MM & $\mathrm{OM}$ & $\mathrm{DM}$ \\
\hline $\begin{array}{l}\text { Soil moisture leveis } \\
\text { (SML) }\end{array}$ & 3 & 1,405 & 1,376 & 1,376 & 2,585 & 4,124 & 0,142 & 0,142 & 15,9376 \\
\hline Linear regression & 1 & $3,142^{\mathrm{ns}}$ & $3,976^{\text {ns }}$ & $3,976^{\text {ns }}$ & $4,886^{\mathrm{ns}}$ & $5,450^{\mathrm{ns}}$ & $0,192^{\text {ns }}$ & $0,192^{\text {ns }}$ & $1,327^{\text {ns }}$ \\
\hline Quadratic regression & 1 & $0,757^{\mathrm{ns}}$ & $0,00004 * *$ & $0,00004 * *$ & $1,094^{\mathrm{ns}}$ & $6,317^{\mathrm{ns}}$ & $0,114^{\text {ns }}$ & $0,114^{\text {ns }}$ & $41,142 *$ \\
\hline Cúbic regression & 1 & $0,315^{\mathrm{ns}}$ & $0,15295^{\mathrm{ns}}$ & $0,15245^{\mathrm{ns}}$ & $1,774^{\mathrm{ns}}$ & $0,605^{\mathrm{ns}}$ & $0,119^{\text {ns }}$ & $0,119^{\text {ns }}$ & $5,3435^{\mathrm{ns}}$ \\
\hline Residue (SML) & 12 & 3,486 & 1,619 & 1,619 & 2,353 & 2,554 & 1,062 & 1,062 & 5,629 \\
\hline Plots & 15 & & & & & & & & \\
\hline Fertilization (F) & 1 & $0,457^{\text {ns }}$ & $1,024^{\mathrm{ns}}$ & $1,024^{\mathrm{ns}}$ & $3,134^{\mathrm{ns}}$ & $0,1495^{\text {ns }}$ & $0,165^{\mathrm{ns}}$ & $0,165^{\text {ns }}$ & $1,879^{\mathrm{ns}}$ \\
\hline $\begin{array}{l}\text { Interaction } \\
(\mathrm{SML}) \times(\mathrm{F})\end{array}$ & 3 & $5,492^{\mathrm{ns}}$ & $0,443^{\text {ns }}$ & $0,443^{\text {ns }}$ & $1,313^{\mathrm{ns}}$ & $3,489^{\mathrm{ns}}$ & $0,704^{\mathrm{ns}}$ & $0,704^{\text {ns }}$ & $12,202^{\mathrm{ns}}$ \\
\hline Resíduo (F) & 2 & 3,56 & 1,071 & 1,071 & 0,701 & 4,548 & 1,207 & 1,207 & 6,575 \\
\hline TOTAL & 31 & & & & & & & & \\
\hline CV\% (SML) & & 12,54 & 4,23 & 1,82 & 29,52 & 30,97 & 11,38 & 1,13 & 34,92 \\
\hline CV\% (F) & & 12,68 & 3,44 & 1,48 & 33,35 & 41,32 & 12,14 & 1,21 & 42,89 \\
\hline
\end{tabular}

$* *=$ significant at 0,01 probability; $*=$ significant at 0,05 probability; ${ }^{\text {ns }}=$ not significant.

Table 5. Crude Protein (CP), Mineral Matter (MM), Organic Matter (OM) and Dry Matter (DM) of saltbush leaves (Atriplex nummularia) at 3 months after cutting.

\begin{tabular}{|c|c|c|c|c|c|c|c|c|}
\hline \multirow{3}{*}{ Treatments } & \multicolumn{4}{|c|}{------------------Leaf---------------- } & \multicolumn{4}{|c|}{------------------Stem---------------- } \\
\hline & \multicolumn{8}{|c|}{$\%$} \\
\hline & $\mathrm{CP}$ & MM & OM & $\mathrm{DM}$ & $\mathrm{CP}$ & MM & $\mathrm{OM}$ & DM \\
\hline $\mathrm{T}_{1}$ & 14,36 & 30,53 & 69,47 & 22,20 & 4,99 & 8,98 & 91,02 & 36,74 \\
\hline $\mathrm{T}_{2}$ & 14,77 & 30,34 & 69,66 & 21,76 & 4,72 & 9,04 & 90,96 & 38,09 \\
\hline $\mathrm{T}_{3}$ & 15,31 & 29,84 & 70,16 & 22,74 & 4,72 & 8,95 & 91,05 & 39,01 \\
\hline $\mathrm{T}_{4}$ & 15,11 & 29,65 & 70,35 & 23,04 & 6,22 & 9,24 & 90,76 & 35,83 \\
\hline Average & 14,89 & 30,09 & 69,91 & 22,43 & 5,16 & 9,05 & 90,95 & 37,42 \\
\hline
\end{tabular}

The Mineral Matter (MM) content was high in leaves (Table 5), showing a quadratic effect for this variable in the treatments (Figure 5A). The soil kept at $100 \%$ FC $\left(\mathrm{T}_{1}\right)$ had a higher MM content $(30.53 \%)$, confirming the enormous capacity of Atriplex in extracting soil salts, which is the main factor that provides the elimination of salts. Moreover, this extensive salt accumulation capacity in the leaf tissue is considered as a major limitation of the use of saltbush as forage, it being necessary to limit the proportion of saltbush in the composition of animal feed since higher ratios may lead to rejection of the plant by the livestock.

Souto et al. (2005), providing sheep with a diet containing $38.30 \%$ of saltbush hay, provided an average daily gain of $145 \mathrm{~g} /$ day to animals. The leaf OM suffered a quadratic effect, behaving inversely to $\mathrm{MM}$, in the treatment with the lowest soil moisture $\left(\mathrm{T}_{4}\right)$. It had the highest proportion of $\mathrm{OM}$ $(70.35 \%)$ (Figure 5B). 
A

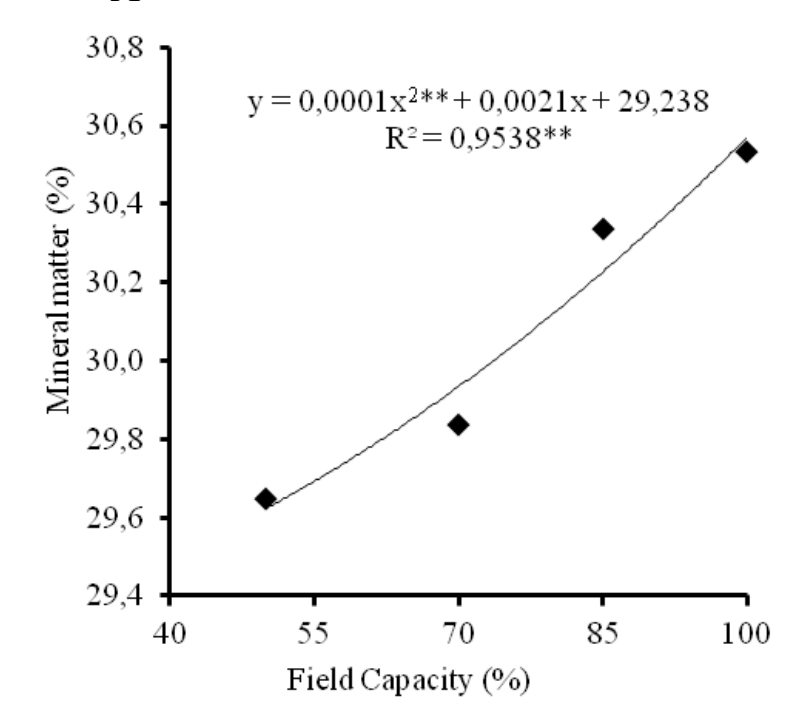

B

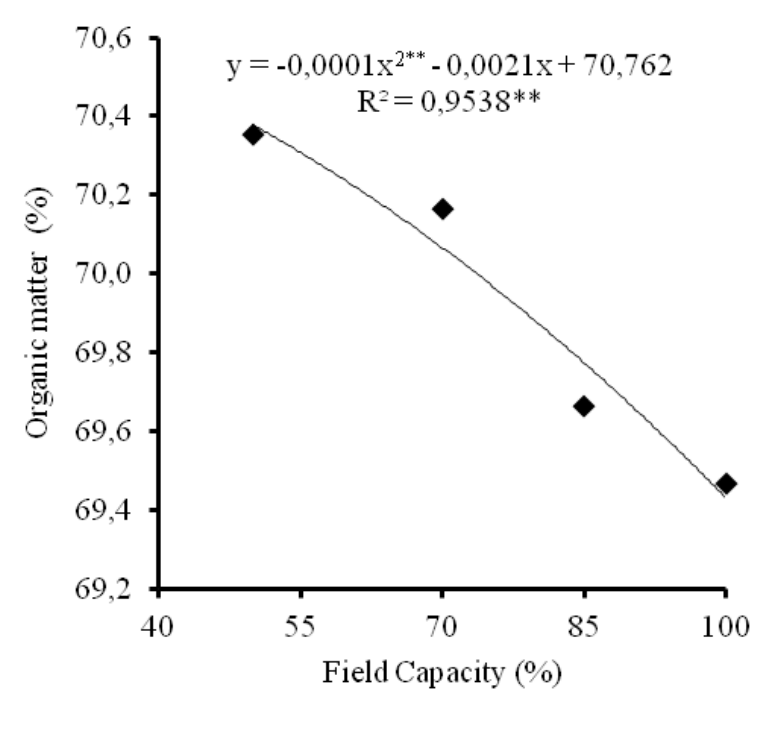

Figure 5. Regression equations relating Mineral Matter (MM) (A) and Organic Matter (OM) (B) of saltbush irrigated with waste from desalination differing in soil moisture level.

Regarding the stem, OM levels were above $90 \%$ for all treatments (Table 5). These data are in agreement with those obtained by Carvalho Junior et al. (2010). As for the DM of leaves, it decreased as the soil moisture in treatments increased. This is the opposite effect to that observed for stem DM where
$\mathrm{T}_{2}$ and $\mathrm{T}_{3}$ were higher (Figure 6). However, the values for leaves were lower than the values obtained for stem DM (Table 5). Leaf and stem DM values, similar to those obtained in this study, are presented in Porto et al. (2001).

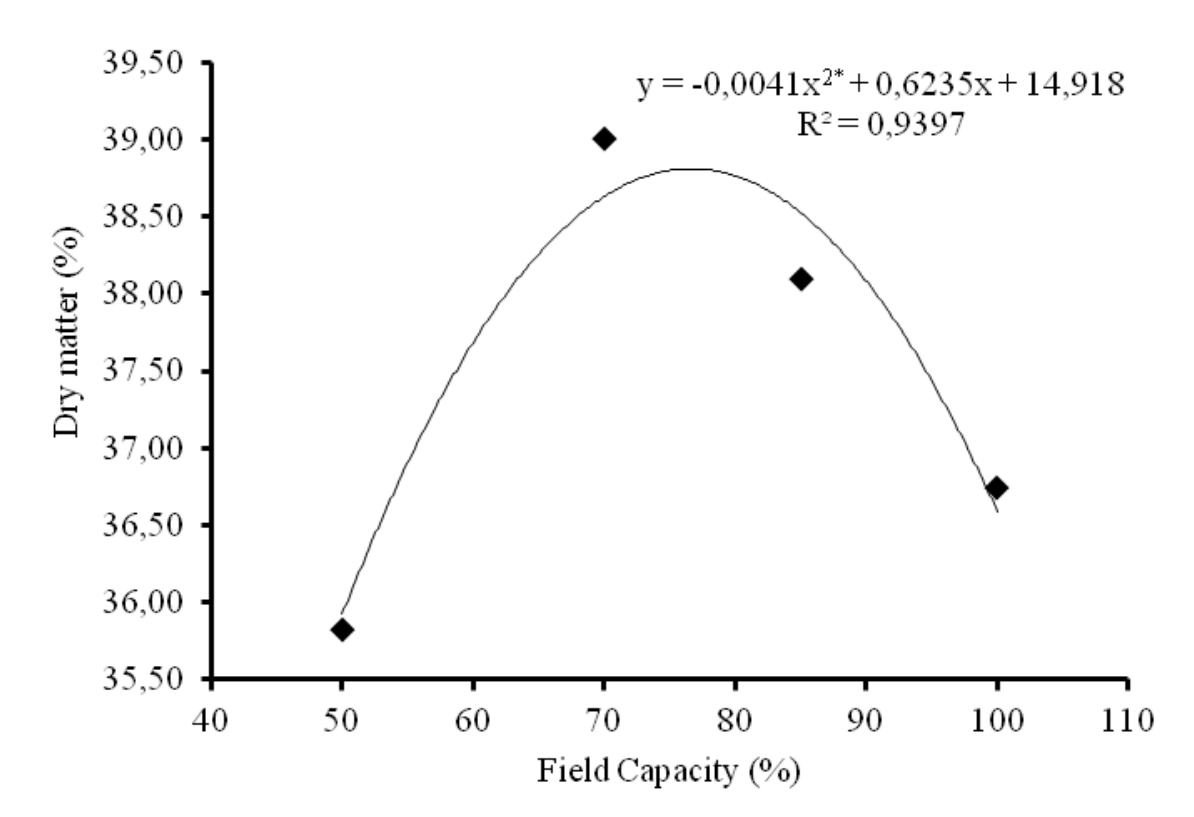

Figure 6. Regression equations relating Dry Matter (DM) (A) of saltbush stems irrigated with waste from desalination differing in soil moisture level.

\section{CONCLUSIONS}

Saltbush fresh and dry matter production with an $85 \%$ soil moisture level in relation to field capacity had the minimum loss of yield, being productive even in the driest soil.

The total yield, fresh and dry, was satisfactory using the reject brine from desalination for the irrigation of saltbush, proving its viability for the production of forage.

The Atriplex nummularia showed a good bromatological quality for all treatments, especially in relation to crude protein. 


\section{REFERENCES}

ANDRADE, R. S.; STONE, L. F. Estimativa da umidade na capacidade de campo em solos sob Cerrado. Revista Brasileira de Engenharia Agrícola e Ambiental, Campina Grande, v. 15, n. 2, p. 111116, 2011.

BARROSO, D. D. et al. Produtividade e valor nutritivo das frações forrageiras da erva-sal (Atriplex nummularia) irrigada com quatro diferentes volumes de efluentes da criação de tilápia em águas salobras. Revista Agropecuária Técnica, Areia, v. 27, n. 1, p. 43-48, 2006.

CARVALHO JÚNIOR, S. B. et al. Produção e avaliação bromatológica de espécies forrageiras irrigadas com água salina. Revista Brasileira de Engenharia Agrícola e Ambiental, Campina Grande, v. 14, n. 10, p. 1045-1051, 2010.

DIAS, N. S. et al. Concentração salina e fases de exposição à salinidade do meloeiro cultivado em substrato de fibra de coco. Revista Brasileira de Fruticultura, Jaboticabal, v. 33, n. 3, p. 915-921, 2011.

SANTOS, H. G. et al. Sistema brasileiro de classificação de solos. 1 ed. Brasília, DF: EMBRAPA, 2000. 412 p.

GLENN, E. P.; BROWN, J. J. Effects of soil salt levels on the growth and water use efficiency of Atriplex canescens (Chenopodiaceae) varieties in drying soil. American Journal of Botany, Rockville, v. 85 , n. 1, p. 10-16, 1998.

MEDEIROS, J. F. et al. Management strategies of saline water on morphometric characteristics of melon cultivars. Revista Engenharia Agrícola, Jaboticabal, v. 34, n. 4, p. 649-659, 2014.

MELLO, C. R. et al. Estimativa da capacidade de campo baseada no ponto de inflexão da curva característica. Revista Ciência Agrotécnica, Lavras, v. 26, n. 4, p. 836-841, 2002.

PORTO, E. R. et al. Rendimento da Atriplex nummularia irrigada com efluentes da criação de tilápia em rejeito da dessalinização de água. Revista Brasileira de Engenharia Agrícola e Ambiental, Campina Grande, v. 10, n. 1, p. 97-103, 2006.

PORTO, E. R.; AMORIM, M. C. C.; SILVA JÚNIOR, L. G. A. Uso do rejeito da dessalinização de água salobra para irrigação da ervasal (Atriplex nummularia). Revista Brasileira de Engenharia Agrícola e Ambiental, Campina Grande, v. 5, n. 1, p. 111-114, 2001.
SILVA, F. de A. S.; AZEVEDO, C. A. V. de. Principal Components Analysis in the Software Assistat-Statistical Attendance. In: WORLD CONGRESS ON COMPUTERS IN AGRICULTURE, 7., 2009, Reno. Anais... RenoNV-USA: American Society of Agricultural and Biological Engineers, 2009.

SILVA, D. J.; QUEIROZ, A. C. Análise de alimentos: métodos químicos e biológicos. 3. ed. Viçosa, MG: UFV, 2002. 235 p.

SOARES, T. M. et al. Destinação de águas residuárias provenientes do processo de dessalinização por osmose reversa. Revista Brasileira de Engenharia Agrícola e Ambiental, Campina Grande, v. 10, n. 3, p. 730-737, 2006.

SOARES, H. R. et al. Lettuce growth and water consumption in NFT hydroponic system using brackish water. Revista Brasileira de Engenharia Agrícola e Ambiental, Campina Grande, v. 19, n. 7, p. 636-642, 2015

SOUTO, J. C. R. et al. Desempenho produtivo de ovinos alimentados com dietas contendo níveis crescentes de feno de erva sal (Atriplex nummularia Lindl). Revista Ciência Agronômica, Fortaleza, v.36, n. 3, p. 376-381, 2005.

SOUSA, R. B. C. et al. Variação sazonal das águas subterrâneas utilizadas para irrigação na microrregião de Tibau, RN. Revista Caatinga, Mossoró, v. 22, n. 4, p. 206-213, 2009.

SOUZA, E. R. et al. Biomass, anatomical changes and osmotic potential in Atriplex nummularia Lindl. cultivated in sodic saline soil under water stress. Environmental and Experimental Botany, Amsterdam, v. 82, n. 1, p. 20-27, 2012.

TERCEIRO NETO, C. P. C. et al. Crescimento do meloeiro pele de sapo irrigado com água salobra com diferentes estratégias de manejo. Revista Caatinga, Mossoró, v. 27, n. 2, p. 87-100, 2014.

VASCONCELLOS, E. B. de C. Dinâmica da água e dos nutrientes no sistema de produção integrado gerado pela dessalinização da água de poço do semiárido brasileiro. 2011. 101p. Dissertação (Mestrado em Ciências: Área de Concentração em Ecologia Aplicada) - Escola Superior de Agricultura "Luiz de Queiroz”, Piracicaba, 2011.

WATSON, M. C.; O'LEARY, W. O. Performance of Atriplex species in the San Joaquin valley, California, under irrigation and with mechanical harvests. Agriculture, Ecosystems and Environment, Amsterdam, v. 43, n. 3-4, p. 255-266, 1993. 